\title{
Capacity Building in Accounting in an Australian University - Lessons for South East Asia
}

\author{
Roger L. Burritt (University of South Australia)
}

\begin{abstract}
Consideration is given to the promotion of and barriers to developing the intellectual capital of academics in triple bottom line accounting for countries in South East Asia. A range of considerations that promote intellectual capacity building in accounting are outlined. The main problems associated with development are also outlined.

Résumé

Le but de cet article est d'analyser le pour et le contre de la formation des universitaires en comptabilité, tout en adoptant une vision de responsabilité sociale (ou de Triple Résultat) dans les pays du sud est asiatique. L'auteur discute des moyens nécessaires pour promouvoir le développement de compétences en comptabilité. Il offre aussi une élaboration des problèmes principaux associés au développement.
\end{abstract}

\section{INTRODUCTION}

Considered in this paper are several key pragmatic reasons supporting and constraining the development of a critical mass of accounting researchers and research/scholarship. This is considered relevant to higher education in South East Asia for a number of reasons.

First, higher education in South East Asia addresses a range of issues common to other countries such as Australia, including: the level of participation (e.g. Thailand 32\% and Cambodia 3\% gross enrolment ratios); diversification between institutions (e.g. public, private - recently in Cambodia, Vietnam, Malaysia, Singapore - and transnational education); international mobility of students and academics importers (Malaysia, Thailand, Vietnam) and exporters (Malaysia, Singapore, Australia); marketisation; budget cuts associated with a neo-liberal ideology; quality concerns; unconducive environments for research because of heavy teaching loads, lack of funds, lack of qualified researchers, etc. (UNESCO 2006: iii \& 2-10, see also Parker 2007: 7).

Second, accounting is claimed to be the language of business at the heart of marketisation, the language that provides the common basis for all stakeholders to understand the performance and accountability of business organisations (Weil, O’Brien, Maher and Stickney 2005). Third, accounting is a tool of economic development, environmental destruction and social injustice, but is necessary for credible entry to global capital markets for needed investment funds (Tayi 2003); 
Fourth, there are mixed messages from companies and auditors about their use of much touted international financial reporting standards (IFRS) for comparability in different countries; for example, in Malaysia and Thailand, companies' and auditors' references are to national accounting standards, but these standards differ significantly from IFRS, or their pace of adoption of IFRS is lagging well behind, whereas in the Philippines national accounting standards are congruent with or may be nearly the same as IFRS (Zeff 2007: 292).

Fifth, there has been a global fixation with financial accounting rather than environmental, social or sustainability accounting even though sustainable development has become a central organizing theme within contemporary society (Schaltegger and Burritt 2006; Unermann et al. 2007: 2). The institutional isomorphic result is a legitimate and social acceptance of IFRSs regardless of their usefulness (Rodrigues and Craig 2007: 742), a situation which needs addressing. Sixth, accountants in academia and practice are in short supply, for example, in China there are 69,000 licensed accountants working for 5,600 firms but the country needs more than 300,000 accountants to meet the growing emphasis on governance and financial control and is looking beyond South East Asia for supply (Coonan 2007). Finally,accountants are mobile and obtain a premium for their services, for example China is witnessing the highest accountant salary inflation in Asia, and high turnover rates (Coonan 2007).

A vibrant academic accounting profession potentially provides important support for oiling the wheels of sustainable development and sustainable society but the lack of intellectual capital hampers such development and bolsters the status quo.

In the less-developed countries of South East Asia, higher education systems are chronically under-funded and face escalating demand, underqualified academic staff and poorly planned curricula. Thus, the result is poorly taught students (UNESCO 2006, p. 2), low availability of academic staff, and a low practical significance of the tangible (transmission of recent knowledge), intangible (development of approach and attitudes to knowledge) and global (department not individual level) teaching-research nexus in the development of intellectual capital (Neumann 1992). The similarity between these traits in higher education in the less-developed countries of South East Asia and traits in the accounting discipline in developed countries is remarkable, and is considered next in the context of one Australian university.

\section{THE NEED FOR ACCOUNTING INTELLECTUAL CAPITAL - THE CASE OF AUSTRALIA}

From a professional perspective key problems in Accountancy in Australia are seen to be highly student-centric (CPA Australia 2006). According to CPA Australia, the largest professional Accountancy body in the country: the number of accountants has increased from 100,000 in 1996 to 140,000 in 2006, but there is an ongoing shortage of accountants; skilled migrant accountants have been 
encouraged in order to make up for this shortage, direct from overseas $(1,237$ in 2002 increased to 2,338 in 2005) and from employment of overseas students awarded permanent residence and not needing prior work experience (933 in 2002 increased to 6,559 in 2006); most rapid growth has been in masters courses and the main source of students has been China; the proportion of accountants born in Australia fell from 71\% to 66\% between 2001 and 2006 with the main increase in new accountants coming from China and India with this trend expected to continue; there is a growing concern about the lack of English language skills for communication, which disadvantages both employers and students, and leads to dissatisfied employers; and the profession projects this situation as leading to a need for (i) higher English language skills of students to be required and (ii) more accounting places to be made available at University for domestic students.

In contrast, from an academic accounting perspective some key elements of change include:

- $\quad$ an ongoing shortage of staff available to teach growing numbers of students;

- a growing emphasis on teaching overseas as well as in the domestic market;

- the substitution of additional teaching for research/ scholastic activity, especially by junior academic staff who perceive themselves to be overloaded;

- $\quad$ expanding roles for accountants and auditors from the narrow financial issues towards aspects of sustainable development including accounting for the environmental and social impacts of business;

- $\quad$ a widening gap between the financial rewards in practice and academia; and

- changes in the technology through which accounting services are delivered - internet, mobile phones, email, xbrl (extensible business reporting language), etc..

Experience related to development of the Centre of Accounting, Governance and Sustainability (CAGS) in the School of Commerce, Division of Business at the University of South Australia (UniSA) places these issues in the context of a Centre specifically established to build intellectual capacity in accounting, and is considered next.

\section{ACCOUNTING DEVELOPMENT AT UniSA AND CAGS}

Some key considerations about UniSA are that: it is a relatively new University in Australia established in 1991 through the amalgamation of the South Australian Institute of Technology and the Magill, Salisbury and Underdale campuses of the South Australian College of Advanced Education; it is part of the Australian Technology Network of universities, and not a member of the Group of Eight research intensive universities; and a strong focus of UniSA is 
on employability of graduating students who can contribute to needs of society educating professionals; multidisciplinary research to benefit the community with sustainability and healthy lifestyles being two of its research priorities; internationalisation (export) of higher education; and equitable access to education - indigenous and disadvantaged socio-economic groups.

Accounting is one major discipline within the Division of Business. Qualified accountants in Australia have been required to complete an appropriate degree (undergraduate or masters) prior to their acceptance into the profession. Hence, the demand for education in accounting has been strong and rising. In particular: before CAGS was established the accounting discipline was without leadership at the professorial level (Level E appointments); the five stage academic staff profile (levels A to E) was heavily biased towards Level A (Associate Lecturer) and B (Lecturer) appointments; staff perceived themselves as being time poor insofar as research was concerned with heavy teaching loads; job opportunities elsewhere, especially in the Group of Eight research intensive universities, were becoming relatively more attractive as many new courses were coming on-stream, new modes of teaching and study periods emerged, teaching loads continued to increase, market loadings to recognise staff shortages were not available; and minimal funding for travel/ conference presentation was available. Hence, staff turnover was high; and few staff possessed doctoral qualifications.

Support was clearly needed to promote intellectual capacity building of the existing and new staff in accounting. CAGS was established at the University of South Australia on 1 January 2007, through a Division of Business Research Concentration Development grant designed:

- to facilitate the emergence of research groupings within the Division to collaborate in common research areas, to provide an environment for research training in an area, and to produce research publications;

- to facilitate the development and enhancement of particular research areas within the Division that can be known by outsiders to the universities as areas for which the University is well-known, for example, to researchers in Australian and overseas universities, research institutions and industry;

- $\quad$ to promote collaborative research and research training activities within the framework of the University's formal agreements and strategic alliances; and

- to increase the competitiveness of the Division's researchers in bidding for external collaborative research funding.

A range of considerations have been supported by CAGS to promote intellectual capacity building in accounting. These include:

- $\quad$ recognition at the top of the university that the discipline was not only important financially but that it needed to perform academically. Motivation for this was partly stimulated by the potential introduction 
by the Australian Government's Research Quality Framework which was to provide significant funding based on research quality and impact of faculty. The first step was to secure the appointment of two accounting Professors from Group of Eight Universities who were research active and give them discretion to develop their research agendas;

- $\quad$ senior management being open to providing resources which would be used to promote research/scholarship as guided by the new professoriate. The business case for funding had to be made but over a period of eighteen months the university, division and school approved almost A\$ 1 million for a three year period to provide research infrastructure in accounting;

- recognition of the need to develop the teaching faculty through: providing the opportunity for staff (i) to be mentored, (ii) to undertake research-based courses (e.g. research methods), (iii) to have support available for developing grant applications; (iv) research and editorial support for articles and conference presentations - through the provision of funding for Research Assistants (3) to be available to help all accounting academics with their research; and (v) a Research Administrator for CAGS to address administrative issues associated with these activities. All staff willing to engage with research/scholastic activities have access to these facilities. Staff whose strength is in teaching receive higher teaching loads;

- $\quad$ building trans-disciplinary support/collaborations/partnerships in areas of accounting associated with environmental and social (sustainability) accounting research (e.g. socially and environmentally sustainable businesses in remote desert communities; biodiversity decisions of farmers in South East South Australia; environmental management accounting in small and medium size businesses in South East Asia; water accounting; timber accounting; carbon emissions accounting);

- $\quad$ supporting visitors and staff engagement in research (for example: by encouraging the hosting of the 2008 A-CSEAR (Australasian - Centre for Social and Environmental Accounting Research) Conference; by supporting regular visits from external scholars; and by providing facilities for visiting Research Fellows;

- $\quad$ obtaining research support and time for developing applications for external funding, accompanied by appointment of a Senior Research Fellow to help develop competitive research funding grants;

- obtaining support from the Accountancy profession, for example, through conference funding and support for a specialised Journal which encourages publishing activities of early career researchers; and

- building the teaching-research nexus through available networks of academics in specialist areas when there is insufficient capacity 
available (e.g. EMAN for environmental management accounting; ACSEAR for social accounting).

In parallel with the previously mentioned developments there are a number of constraints on potential success. The main problems are:

- continued staff turnover - since CAGS was established 5 out, 5 in, including one out and one in at the Professorial level;

- the lack of a prior intellectual culture because the institutions which came together to found UniSA were originally teaching institutions and staff who only wish to be teachers remain;

- greater acceptance of employing teaching only staff in accounting in the main research intensive universities as the growing shortage of 'rounded' or research-based staff continues, thereby creating additional demand for staff who do not wish to research;

- the availability of alternatives (e.g. overseas teaching) to academic staff who could be pursuing research/scholastic activities has not diminished;

- the pressure from performance management criteria weighted against the pursuit of intellectual endeavours;

- concern for measuring the past quality of intellectual performance rather than the future potential of intellectual innovation;

- the shortage of future academic accountants caused by the increasing shortage of accounting graduates; and

- $\quad$ engaging the professional Accountancy firms and bodies in a research supporting role.

Development of accounting in higher education to support sustainable development involves addressing these and related issues.

\section{DISCUSSION AND CONCLUSIONS}

From the above observations, shortage of research-orientated academic accounting staff in higher education appears to be a common feature in both South East Asia and Australia. Both regions are affected by a market shortage in the current environment of economic development and the desire to attract international capital for investment.

This shortage looks set to deteriorate further because some South East Asian countries are seeing an awakening demand for accountants given their engagement with market economies. For example Coonan (2007: 36) reminds us 'There is an interesting history behind China's shortage of accountants. During the Cultural Revolution China experienced a vacuum of accountants and other qualified professionals amid a period of social instability. Accountancy courses in universities were shut down, and intellectuals were widely denounced.' We need to be mindful that in Cambodia the Kampuchea Institute of Certified Public Accountants and Auditors (KICPAA) has only recently been established and university education of accountants instituted, having being preceded up to 1991 
by the Khmer Rouge regime, led by Pol Pot, which killed most of the professionals in all disciplines in Cambodia including accountants and wiped out most of the elite, social and physical infrastructure in the country (Bopta et al. 2007).

As mentioned above, accounting is said to be the language of business, but if the wrong language is adopted or encouraged, for example an accounting which distances itself from social and environmental impacts, society could suffer the consequences of adopting the market-based status quo. As the total demand for conventional accountants educated in higher education institutions increases, there is a need for a parallel engagement of academic accountants prepared to consider, research and engage in scholarly activity which questions a status quo which leaves sets of social inequities and environmental impacts unaddressed. Development of a new accounting profession could be used to employ accounting academics who challenge existing practices and provide potential future accountants with a rounded education.

Building intellectual capital in the accounting discipline through higher education within South-East Asia could be of great significance if the interrelated benefits - economic, social and environmental - of the growing interdependency of countries are to be reaped.

Triple bottom line, sustainability thinking, sustainability accounting, reporting and accountability do not yet form part of the mainstream language of business and represent a global challenge for research in accounting. Academic accounting scholars seek to explore and explain the importance of such thinking. However, the presence of opportunities and incentives for accounting graduates and existing academics to engage with research or seek their fortunes outside academia means that there is a dearth of capacity and talent being encouraged to consider critical issues in accounting - in South East Asia, Australia and other countries. Countries which have experienced a political or militaristic truncation of accounting resources now have to come to terms with a market-induced shortage of resources and institutional pressures for conformity. In this regard, the experience of one academic accounting intellectual capacity building exercise at the Centre for Accounting, Governance and Sustainability at the University of South Australia provides some guidance as to how progress might be achieved. 


\section{References}

Bopta, C., Yapta, C.W.S. \& Jacobs, K. (2007). The Re-emergence of Accounting Profession in ASEAN: the case of Cambodia. Accounting and Finance Association of Australia and New Zealand (AFAANZ) Conference, Gold Coast, Australia, July 2007.

Coonan, C. (2007). Shortfall in China. Intheblack, 77(7) 36.

CPA Australia (2006) The Changing Face of the Accounting Profession in Australia, Centre for Population and Urban Research Monash University, Report prepared by Birrell, B., November 2006, pp.17.

Neumann, R. (1992). Perceptions of the teaching-research nexus: a framework for analysis. Higher Education ,23(2) p159-171.

Parker, L. (2007). Universities Redefined: Engines of Commerce, plenary keynote address. 29th EAIR Forum of The European Higher Education Society, Innsbruck, Austria, August 2007.

Rodrigues, L.L. \& Craig, R. (2007). Assessing international accounting harmonization using Hegelian dialectic, isomorphism and Foucault. Critical Perspectives on Accounting, 18(6), 739-757.

Schaltegger, S. \& Burritt, R.L. (2006). Sustainability Accounting and Reporting: Development, Linkages and Reflection. In S. Schaltegger, M. Bennett, \& R.L. Burritt (Eds.), Sustainability Accounting and Reporting. Dordrecht, Netherlands: Springer.

Tayi, H.E.N.(2003). The Cambodian Standards on Auditing and International Auditing Standards. National Accounting Council, Ministry of Economy and Finance.

Unermann, J., Bebbington, J. \& O’Dwyer, B. (2007). Introduction to sustainability accounting and accountability. In J. Unermann, J. Bebbington \& B. O’Dwyer (Eds.), Sustainability Accounting and Accountability. London, England and New York, NY, USA: Routledge.

United Nations Educational, Scientific and Cultural Organization (UNESCO). (2006). Higher Education in South-East Asia. Asia-Pacific Programme of Educational Innovation for Development. Bangkok, Thailand: UNESCO.

Weil, R.L, O'Brien, P.C., Maher, M.W., Stickney, C.P. \& Fitzgerald, K. (2005). Accounting: The Language of Business, 11th edition. Glen Ridge, NJ, USA: Thomas Horton \& Daughters.

Zeff, S.A. (2007). Some obstacles to global financial reporting comparability and convergence at a high level of quality. The British Accounting Review, 39(4), 290-302.

Roger L. Burritt is a Professor, and the Director of the Centre for Accounting, Governance and Sustainability at the School of Commerce at the University of South Australia, Adelaide. He can be reached at roger.burritt@unisa.edu.au. 